\title{
PRIVATE LIVES, PUBLIC ISSUES: CHILDBEARING EXPERIENCES OF ADOLESCENT MOTHERS IN THE ERA OF HIV AND AIDS IN BHAMBAYI, KWAZULU-NATAL, SOUTH AFRICA
}

\author{
Tanusha Raniga, Sibonsile Mathe
}

\section{INTRODUCTION AND PROBLEM FORMULATION}

In poor communities, where early childbearing is common, adolescent girls are not only prone to HIV infection and economic exclusion, but are subjects of sexual exploitation by older adolescent and adult men. It is also widely acknowledged that sex at an early age and with an older partner has been linked with increased risks of unwanted pregnancies, childbearing and HIV risk (Fawole, Asuzu \& Oduntan, 1999; Maharaj, 2006; Manlove, Teery-Humen \& Ikramullah, 2006; Manzini, 2001; Rutenberg, Kaufman, MacIntyre, Brown \& Karime, 2003). Moreover, in the provinces of Gauteng and KwaZulu-Natal, one in three young mothers are infected with HIV (Hanga, Kubai, Mwaura \& Ayanga, 2008:107). A quantitative survey conducted by Manzini in 2001 on childbearing among adolescent girls revealed that of a sample of 796 almost half had already engaged in sex at age 16 and had confirmed unwanted pregnancy. Singh and Darroch (1999) argued that the high incidence of adolescent childbearing in the developing countries is inversely related to socio-economic development and not linked to behavioural and/or sexual choices. However, the complex social dynamics underpinning adolescent childbearing means that the situation is not simply a matter of improving public policy and access to reproductive counselling and health services, but that psycho-social and economic obstacles need to be taken into account (Singh \& Darroch, 1999). Additionally, the World Health Organisation (2003) stipulates that gender inequalities, economic hardship and poverty are conditions that create the breeding ground for sexual violence against women and high rates of unwanted adolescent pregnancies. Bhana (2009) takes these arguments further and maintains that what adds to the complexity of this social problem in contemporary South Africa is large-scale social forces underwritten by the legacies of apartheid and colonialism, including persistent poverty, and racial and gender inequalities.

Bearing the above considerations in mind, this paper presents empirical evidence from one phase of a broader study which adopted qualitative methodology to gain a better understanding of the correlates of poverty, gender relations and HIV and AIDS on the childbearing experiences of fifteen adolescent mothers who reside in a predominantly informal settlement, named Bhambayi, Inanda in KwaZulu-Natal. Using feminist social work theory this paper deliberates three important themes that are closely intertwined: complex sexual choices, the devastating effects of HIV and AIDS on the family, and survival strategies. A central premise of this paper is that the impact of socio-economic, gendered power relations and HIV and AIDS are profound structural factors that shape the identities and life choices of the adolescent mothers in Bhambayi. A critical focus of this study was on providing the participants with an opportunity not just to share their life experiences, but on re-conceptualising dependency (Dominelli, 2002). The paper concludes with some questions concerning transformative interventions and the need for practitioners to advocate for effective health, economic and social policies and programmes as the way forward, if social development objectives are to be realised. 


\section{DELIBERATING PRIVATE LIVES AS PUBLIC ISSUES}

Feminist social work - which has traditionally been influenced by feminist theories to raise consciousness, provide an analysis of oppression and empower women to take control of their lives (Payne, 1991) - formed the theoretical foundation for this study. Feminist thought in social work research and practice has over decades played a fundamental role in not just acknowledging the oppressed and subordinate position and conditions of women, but also in challenging the "dual mission" notion of individual versus social change that has bifurcated the curricula of most schools of social work (Dominelli, 2002; Hammer \& Statham, 1999; Landes, 1998; Orme, 2002). In fact, Baines (2007) warns that if social workers are not prepared to adapt their knowledge, assume new roles and make the adjustments required for embracing feminist theories, then the profession stands the risk of becoming marginalised. Dominelli (2002:18) criticises social workers for adopting traditional interventions, which tend to help women cope more adequately with their prescribed roles and responsibilities. She thus argues further that feminist social work exhibits "such a rooted sense that to be caught up in feminism is to be caught up practically in changing the way things are done".

This research took the adolescent mothers' experiences of the world as the starting point of its analysis and the central focus was on helping these young women to understand the correlates of poverty, gender relations and HIV and AIDS on their childbearing experiences and on their life choices. This meant that by rooting the adolescent mothers' troubles in their social positions as young, black women from an impoverished community affected by HIV and AIDS, the stigma, shame and guilt that they felt were removed (Dominelli, 2002). Many feminist writers contend that gender inequities, power imbalances, undeveloped negotiation and decision-making skills as well as sexual exploitation by older partners are primary factors contributing to high rates of adolescent pregnancies and HIV infection among young women (LeClerc-Madlala, 2001; Moletsane, Morell, Unterhalter \& Epstein, 2002; Sewpaul, 2006; Van Rensburg \& Horsten, 2004).

\section{RESEARCH METHODOLOGY}

\section{The research context}

Bhambayi, like other informal settlements in South Africa, is characterised by high levels of poverty, limited access to basic nutrition, poor access to economic opportunities and inadequate social services. The community is located in Inanda which is about $35 \mathrm{~km}$ outside of Durban. There are 920 formal houses built as a result of a collaborative development effort between the eThekwini Municipality and the local civic structure called the Bhambayi Reconstruction and Development Forum (BRDF). In the past decade an estimated 1800 informal houses were built by people who had migrated from the rural areas in KwaZulu-Natal as well as from the Eastern Cape and neighbouring African countries. The area has no recreational facilities for adolescents. The Provincial Department of Health operates a monthly mobile clinic and a Drop In centre (NIP), where HIV testing and material support in the form of daily meals and grocery hampers are provided to families who are affected by the pandemic. The majority of the residents in Bhambayi speak isiZulu.

\section{The research process}

The University of KwaZulu-Natal: Community Outreach and Research unit has over the past 12 years facilitated a student training unit in Bhambayi, where third- and fourth-year social work students provided casework, group work and community work services to residents. Over the years it became evident that many families encounter daily struggles as a result of severe 
poverty and HIV and AIDS. In 2007 the BRDF approached the University to research the effects of poverty and HIV/AIDS on households. Ethical clearance was obtained in June 2007 from the Research Committee of the University of KwaZulu-Natal to conduct this study. Phase one of the study comprised a quantitative household-based (351) survey (Raniga \& Simpson, 2010). This paper reports on Phase two of the larger study, which qualitatively aimed to:

- explore the factors that contributed to adolescent mothers' decisions on early childbearing;

- gain an insight into the impact of HIV and AIDS on their daily lives;

- explore suggestions for transformative action.

\section{Our participants}

Using feminist methodology the researchers were guided by a three-pronged simultaneous process of assessment, engagement and planning (Morris, 2006). The assessment phase comprised a literature review of the topic of adolescent childbearing using the feminist worldview, which focused particularly on the interface of poverty, gender and health factors. The engagement phase involved several meetings with the BRDF committee members regarding the objectives of the study and ideological position of the researchers.

The researchers were mindful of Morris's (2006:141) assertion that "it is involvement, commitment and potential to affect empowerment that guide selection of participants in a feminist study". Hence the selection followed a purposive process where fifteen adolescent mothers were chosen using the following guidelines:

- They were victims of gendered oppression;

- They were from households that were affected by HIV and AIDS;

- They were willing to engage in a discussion of gendered oppression and its link to their decisions regarding childbearing;

- They were willing to commit to action strategies regarding empowerment;

- They were willing to exchange ideas and share their life experiences in a group setting.

Finn and Jacobson (2003:186) describe such engagement as "socio-emotional, practical and a political process of coming together with others to create a space of respect, hope, to pose questions and learn about one another". The plan entailed strategies for identifying the adolescent mothers, engaging with stakeholders in the community, engaging participants in a dialectic reflexive process, recording and analysing the data that described their experiences of gendered oppression and jointly engaging in strategies to take action. Throughout the process, the researchers were committed to respecting the uniqueness of every participant within her social situation - thus recognising the adolescent mothers' single identities while affirming their collective solidarities (Dominelli, 2002). The research process allowed the adolescent mothers to examine the commonalities of their childbearing experiences alongside the specificities of their particular life positions.

Morris (2006:145) explains that feminist research encompasses "a circular process of understanding, connecting, empowering, taking action and reflecting on the action". The researchers were mindful of four major activities throughout the research process: looking, thinking, critical self-reflection and action. As such the researchers and the participants were equal partners in collecting data on gendered oppression and strategies for empowerment (Morris, 2006). 


\section{Data-collection process}

One semi-structured in-depth interview followed by four focus group sessions was held with the 15 adolescent mothers. The semi-structured in-depth interview gave the researchers an opportunity to discuss the objectives of the study, to explore whether the participants were willing to share their life stories in the focus group sessions and to establish them as equal partners in the research process (Baines, 2007). Secondly, it provided the forum for engaging the adolescent mothers in understanding their life experiences within the broader socioeconomic and gendered framework. This "conscientisation", which is central to Freirean thought, draws on the element of human awareness which allows for the capacity of creative thinking and thus the potential to transform rather than merely adapt to social reality. As Freire (1993:41) eloquently states, "by acting upon reality, people can seek improvement in their lives and become more fully human". Each narrative collected during the in-depth interview provided insight into how living in an impoverished community with high levels of HIV and AIDS had a profound impact on their sexual choices. Enabling women to tell their own stories and speak of their experiences is integral to feminist ways of gathering knowledge and understanding of the world (Dominelli, 2002).

Throughout the data-collection process there was ongoing mutual negotiation of meaning and power among the researchers and the adolescent mothers. The power hierarchy between researchers and the researched was replaced by egalitarian and genuine relationship (Morris, 2006).

The focus group sessions triangulated the in-depth interview as the aim was to encourage the adolescent mothers not just to see their private troubles as public issues, but to involve them in collective action with a commitment to improving their life circumstances and assisting them to overcome isolation and learned helplessness (Dominelli, 2002). At the onset of the study the researchers envisaged conducting one focus group session with the adolescent mothers. However, through adopting a dialectic reflexive approach consistent with feminist methodology, both the researchers and adolescent mothers collaborated to uncover information, making it meaningful in the context of considering the structural forces and patterns that shaped their experiences, where the partners brought collective wisdom, translating and synthesising data into a guide for transformation. A total of four sessions were held (Finn \& Jacobson, 2003).

The duration of the focus group meeting was 1.5 hours per session. The topics covered in the four sessions included sex and sexuality, factors that led them to have a child, the impact of HIV and AIDS on their lives, and future aspirations.

One major challenge experienced during the focus groups was time as a number of mothers had to leave to take care of relatives and/or feed their babies. Since this study presents the findings from a small sample of fifteen adolescent mothers, the findings cannot be generalised. However, prolonged engagement and the rich descriptive details shared by the participants about their childbearing experiences in both the semi-structured in-depth interview and the focus group sessions served to enhance the reliability and trustworthiness of the findings (Terre Blanche, Durrheim \& Painter, 2006).

Morgan (1988:64) illustrated two approaches to analysing qualitative data. The one is an ethnographic summary and the other a systematic coding via content analysis. The researchers used a combination of these two approaches. Morgan (1988:65) contends that "there is likely to be a cycling back and forth between the raw material in the transcripts and the more abstract 
determination of what topics will go into the ultimate report". Additionally, the data were thematically and critically analysed in relation to existing literature (Terre Blanche et al., 2006) and feminist social work theory. As such, the researchers were constantly mindful of interpreting the adolescent mothers' experiences in relation to gender oppression as constructed by the complex interplay of socio-cultural, health and economic forces (Dominelli, 2004).

Three important themes that are closely connected and that emerged from the data analysis are discussed below: complex sexual choices, the devastating effects of HIV and AIDS on the family, and survival strategies.

\section{DISCUSSION OF FINDINGS}

The empirical findings presented emerged from the analysis of the in-depth semi-structured interviews and four focus group sessions held with fifteen adolescent mothers, as well as from the consensus discussion between the researchers on the analysed data.

The discussion on the findings will be presented in two sections:

- A biographical profile of the participants; and

- A discussion of three closely connected themes, namely complex sexual choices, the devastating effects of HIV and AIDS on the family, and survival strategies.

Table 1 presents the biographical profile of the research participants.

TABLE 1

BIOGRAPHICAL PROFILE OF THE SAMPLE GROUP OF ADOLESCENT MOTHERS

\begin{tabular}{|c|c|c|c|c|c|}
\hline $\begin{array}{c}\text { Participant } \\
\text { number }\end{array}$ & Age & Marital status & $\begin{array}{l}\text { Number of } \\
\text { children }\end{array}$ & $\begin{array}{l}\text { Age at time } \\
\text { of birth of } \\
\text { first child }\end{array}$ & $\begin{array}{l}\text { Highest } \\
\text { level of } \\
\text { education }\end{array}$ \\
\hline 1 & 15 & Single & 1 & 14 & Grade 6 \\
\hline 2 & 17 & Single & $\begin{array}{ll}\text { 1. } & \begin{array}{l}\text { Pregnant with } \\
\text { second child }\end{array}\end{array}$ & 16 & Grade 9 \\
\hline 3 & 17 & Single & 1 & 16 & Grade 7 \\
\hline 4 & 17 & $\begin{array}{l}\text { Living with } \\
\text { boyfriend }\end{array}$ & 1 & 15 & Grade 8 \\
\hline 5 & 19 & Single & 1 & 16 & Grade 10 \\
\hline 6 & 18 & $\begin{array}{l}\text { In committed } \\
\text { relationship }\end{array}$ & 1 & 16 & Grade 11 \\
\hline 7 & 15 & Single & 1 & 14 & Grade 7 \\
\hline 8 & 18 & Single & 1 & 16 & Grade 10 \\
\hline 9 & 19 & $\begin{array}{l}\text { In committed } \\
\text { relationship }\end{array}$ & $\begin{array}{l}\text { 1. Pregnant with } \\
\text { second child }\end{array}$ & 17 & Grade 11 \\
\hline 10 & 20 & Single & 2 & 17 & Grade 12 \\
\hline 11 & 22 & Single & 2 & 18 & Grade 11 \\
\hline 12 & 16 & $\begin{array}{l}\text { In committed } \\
\text { relationship }\end{array}$ & 1 & 15 & Grade 8 \\
\hline 13 & 18 & Single & $\begin{array}{l}\text { 1. Pregnant with } \\
\text { second child }\end{array}$ & 16 & Grade 9 \\
\hline 14 & 19 & Single & 1 & 16 & Grade 10 \\
\hline 15 & 15 & Single & 1 & 14 & Grade 6 \\
\hline
\end{tabular}


Seven of the participants were aged 15-17 years, while eight were between 18 and $22(\mathrm{~N}=15)$. The mean age at the time of first birth was 16. This is consistent with research conducted by Manzini (2001) and Rutenberg et al. (2003), who found that more than one third of young women in KwaZulu-Natal become pregnant before the age of 20. Only one participant had completed secondary school, while four had primary school education and 10 had up to Grade 11 of secondary school education. It was not surprising that the majority stated that they had to leave school as a result of the unexpected pregnancy. At the time of the study all the adolescent mothers were unemployed and in receipt of the child support grant of R240 (amount received at time of study). Magadi (2006) argues that the most compelling reason to keep young teenage girls in school is that a lack of education increases the vulnerability of young women to engage in high-risk behaviours such as unprotected and transactional sex. Additionally, all the adolescent mothers admitted to having had their first child with partners who were on average eight years older than themselves. This is consistent with the findings of a California study conducted by Males (1994:407) that revealed that "men over age 20 account for 77\% of all births among girls of high school age (16-18 years)".

All of the adolescent mothers were single, with four being in committed relationships. As consistent with research conducted by Maharaj (2006), the participants in this study revealed that most of these pregnancies were unwanted, unplanned and occurred outside of marriage.

\section{Complex sexual choices}

One of the major contradictions of the era of HIV and AIDS is that it has contributed to a deeper understanding of how the interplay of poverty and gender profoundly impacts on the sexual behaviour of women (Moletsane et al. 2002; Sathiparsad \& Taylor, 2006). The gender stereotype is that women are expected to be responsible for birth control, be passive, ready and ignorant about sex (Moletsane et al., 2002; Sathiparsad \& Taylor, 2006). What adds to the complexity in South Africa is high rates of poverty and inequality that place young African women in a vulnerable position of engaging in risky behaviour such as cross-generational and transactional sex. This theme is consistent with a World Health Organisation (2003) study which concluded that young women with low educational levels which are closely connected to a lack of economic opportunities were more likely to engage in sex with older men for commercial reasons.

Eight of the adolescent mothers spoke about having partners at least 8-10 years older than themselves who were able to fill their material needs.

My boyfriend paid for my clothes, cell phone and gave me cash every month.

He used to support me and my baby when he had a job, but now he is unemployed.

My boyfriend who was a taxi driver bought groceries for the whole family every month.

It was easier for me to move out and live with my boyfriend as it meant one less mouth to feed in my home.

According to a Population Services International study of cross-generational relationships, between 12 and 25 percent of young women's partners in Sub-Saharan Africa were 10 or more years their senior (HIVAN, 2003). Consistent with this study, the findings revealed that for the young women involved in these transactional sexual relationships, the risk of HIV/AIDS was not a priority concern. Instead, the adolescent mothers confessed that the material benefits were appealing. Shardia Nania, a volunteer counsellor for the Family Life Centre, stated that "school girls see older wealthier men with the 'three Cs' - a car, a cellular phone and cash" (HIVAN, 2003). Another qualitative study concluded that adolescent women fear more negative reactions 
from older partners than from similarly aged partners, if they bring up using condoms or other contraceptives (Manlove et al., 2006). It was thus not unusual that the adolescent mothers had reduced negotiation power in their relationships with the older males.

Hence another important issue on sexual identities that emerged from the focus group sessions was the influence of socio-cultural norms and practices that prevent women from controlling their bodies and negotiating terms for safe sex practices and which increases the vulnerability of females to unplanned pregnancy and HIV infection (LeClerc-Madlala, 2001; Moletsane et al., 2002; Sewpaul, 2005; Van Rensburg et al., 2002). Nine of the participants confessed to having had unprotected sex with their older partners and that they were afraid to suggest the use of condoms.

I made a mistake because now I am HIV+ and he does not support me and my baby.

My boyfriend was drunk and we did not use condoms.

A central focus of the focus group sessions was on raising consciousness about the complex interplay of power imbalances and living in a poverty-stricken community where putting food on the table is a daily struggle that profoundly contributed to their sexual choices. The researchers were mindful of not reinforcing the adolescent mothers' feelings of guilt, shame and self-blame. Instead, for many of the participants this sharing of these events became a liberating experience in which they collectively sought alternative ways of transforming the quality of their lives.

\section{The devastating impact of HIV and AIDS on households}

The most severe impact of the pandemic is experienced at the household level. It is here that low resources, inadequate social services, limited access to basic nutrition and lack of economic opportunities combine to create a disabling environment for those who are infected and affected (Raniga, 2006).

Six of the adolescent mothers were infected with HIV, while nine were affected by AIDS in two main ways. Five adolescent mothers spoke of having lost their biological mother as a result of AIDS in the past year, while one revealed having lost both parents. The other three were left to care for either a sick parent or sibling who was living with AIDS in the household.

Some comments made by the participants were:

I spend my day cooking, bathing and caring for my sick sister;

All I do is cook, clean and look after the baby and my sick mother;

I have no hope for the future because I am always caring for sick people at home;

It is depressing to work and take care of others all day.

This corroborates Van Dyk's (2005) as well as Dube and Kanyora's (2004) assertion that, as the impact of HIV and AIDS increases, adolescent girls bear the burden of caring for older siblings and sick parents. Danziger (1994 cited in World Health Organisation, 2003:20) reveals that in Africa the "combined physical and emotional burdens of caring for sick family members and ensuring their food security under harsh economic conditions often takes a toll on women's own health and well being". Some of the mothers in the focus group sessions spoke of being depressed and lonely as their core function was maintaining the household, not knowing where the next meal was coming from, and caring for the baby as well as the sick relatives. The implications are that in an impoverished community such as Bhambayi, adolescent mothers experience a double jeopardy. The high rates of unemployment, which translates to lack of food 
security as well as the stigma attached to caring for a sick relative dying of AIDS, place young women at the bottom rung of the social strata.

\section{Survival strategies}

Families have long been the most important institutional safety net in responding to childbearing and unwanted pregnancy. Mpedi and Darimont (2007) refers to this system as private household-based safety nets, which in African communities have traditionally included the provision of food, shelter, money and childcare by members of the extended family. Such systems have the dual purpose of providing material and psychosocial support. However, in the era of HIV and AIDS the participants revealed that this traditional support was being challenged. Four of the adolescent mothers revealed that, even though the burden of care giving for a sick relative as well as their own children was physically and emotionally draining, living in an impoverished community gave them little or no choice. Some of their voices are as follows:

My family were happy when I moved out of home because they said it was one less mouth to feed...

As long as I contribute my CSG to the family every month I am able to live here with my child...

I have to wash clothes for the neighbours to earn money so that I can give my boyfriend's family ... These days money changes the way we help each other...

It was evident from the above comments that all the adolescent mothers were expected to contribute money to the households in which they resided. Additionally, all the participants were in receipt of the child support grant as a major source of consistent income. BejacmarDidier (2005) warns that both the private household-based safety net and the state child support grant are inadequate to help adolescent mothers to get out of the poverty deprivation trap. This limited their future aspirations and increased their vulnerability to making poor sexual choices. WHO (2003) stated that when sex "buys" food, shelter, or safety, it is very difficult to follow HIV prevention messages that call for a reduction in the number of sexual partners. Similarly in Haiti, single mothers faced with trying to balance the multiple demands of family and economic survival often entered into a series of sexual relationships, called plasaj, in order to obtain food and housing for themselves and their children (WHO, 2003). Further qualitative research that will determine more sustainable safety nets that will be essential and beneficial to adolescent mothers is required.

\section{CONCLUSIONS AND RECOMMENDATIONS}

The voices of fifteen adolescent mothers in this qualitative study conducted in a predominantly impoverished community called Bhambayi have shown that their childbearing experiences are not just private issues, but are profoundly linked to public, structural concerns such as poverty, economic exclusion, HIV/AIDS and gender inequalities. The findings of this study also corroborate other South African research by Harrison (2007), Rutenberg et al. (2003) and Manzini (2001) that sexual relations with older men in communities has been linked to unwanted pregnancies, childbearing and HIV risk. In fact, the findings revealed that for the young adolescent mothers who were subject to dire poverty and involved in these transactional sexual relationships, the material benefits were attractive and outweighed the risks of HIV infection. 
Of serious concern is the finding that all of the adolescent mothers were either infected and/or in households that were affected by the HIV pandemic. Caring for terminally ill individuals who were dying of AIDS as well as their own young children was acknowledged as a major psycho-social and emotional burden borne by the adolescent mothers, compounded by the daily struggles of poverty. This is clearly an area that warrants further qualitative research. Moreover, a more comprehensive social security system that moves away from reliance on cash transfers such as the child support grant is necessary to help adolescent mothers who reside in households where there is no other source of income and that are affected by HIV and AIDS.

As such there is an urgent need for national and provincial policies to include the concerns of adolescent mothers who are chronically poor, economically excluded and either infected and/or affected by HIV/AIDS to ensure that their basic needs are met and that they have access to health and social services.

The central premise of this study was the need to move beyond the rhetoric of not just giving young adolescent mothers the opportunity to dialogue and express their private troubles, but to involve them in collective action with a commitment to improving their life circumstances through transformative interventions. At the last focus group session the adolescent mothers revealed that they found the weekly meetings a good support network and they wanted to continue meeting to share their life stories and explore options for livelihood strategies. The researchers linked the group with a community-based organisation that provided social services in Bhambayi that had agreed to facilitate the support group and explore livelihood projects that the women were keen to implement. Hence a positive outcome of the study was that the focus groups evolved into a support group. This transformative action, where research becomes a tool for social change, was consistent with what Baines (2007) claims is a fundamental form of feminist social work practice.

Based on these conclusions, the following recommendations are made:

- Transformative interventions should include addressing sexuality through effective health, economic and social policies and programmes;

- It is important to relate social development activities directly to objectives that include poverty reduction, more equal distribution of wealth and income, better access to improved public health and welfare services, and greater gender equality;

- This study represented a limited sample of 15 African adolescent mothers from an impoverished community and does not reflect the population groups in contemporary South Africa in a representative way. The researchers thus recommend further qualitative research to be conducted with a mixed-race profile of adolescent mothers from different provinces across South Africa.

\section{REFERENCES}

BAINES, D. 2007. Doing anti-oppressive practice, building transformative politicized social work. Canada: Fenwood Publishing.

BEJACMAR-DIDIER, M. 2005. The impact of social support structures and economic support on the economic well-being of low-income African-American adult mothers who began childbearing as adolescents. Howard University. (Unpublished PhD Thesis)

BHANA, D. 2009. "They've got all the knowledge": HIV education, gender and sexuality in South African primary schools. British Journal of Sociology of Education, 30(2):165-177. 
DOMINELLI, L. 2002. Feminist social work theory and practice. New York: Palgrave MacMillan.

DOMINELLI, L. 2004. Social work: theory and practice for a changing profession. Cambridge: Polity Press.

DUBE, M.W. \& KANYORA, M.R.A. 2004. Grant me justice: HIV/AIDS and gender readings of the Bible. South Africa: Cluster Publications.

EAST, P., KIERNAN, E. \& CHAVEZ, G. 2003. An evaluation of California's adolescent sibling Pregnancy Prevention Program. Perspectives on Sexual and Reproductive Health, 35(2):62-70.

FAWOLE, O.I., ASUZU, M.C. \& ODUNTAN, S.O. 1999. Survey of knowledge, attitudes and sexual practices relating to HIV infection AIDS among Nigerian secondary school students. African Journal of Reproductive Health, 3:15-24.

FINN, J.L. \& JACOBSON, M. 2003. Just practice: a social justice approach to social work. Peosta: Eddie Bowers Publishing Company Inc.

FREIRE, P. 1993. Pedagogy of the oppressed $\left(20^{\text {th }}\right.$-Anniversary edition). New York: Continuum.

HAMMER, J. \& STATHAM, D. 1999. Women and social work: towards a womancentered practice $\left(2^{\text {nd }}\right.$ ed). London, England: Macmillan.

HANGA, T.M., KUBAI, A.N., MWAURA, P. \& AYANGA, H. 2008. Women, religion and HIV/AIDS in Africa: responding to ethical and theological challenges. South Africa: Cluster Publication.

HARRISON, D. 2007. Three ways to reduce teen pregnancy in South Africa. [Online] Available: http://www.hsrc.ac.za/Document-2679.phtml. [Accessed: 02/12/2009].

HIVAN 2003. Population Services International study of cross-generational relationships. [Online] Available: http://www.hivan.org.za/arttemp.asp?id. [Accessed: 30/07/2003].

LANDES, J.B. 1998. Feminism, the public and the private. New York: Oxford University Press.

LECLERC-MADLALA, S. 2001. Virginity testing: managing sexuality in a maturing HIV/AIDS epidemic. Medical Anthropology Quarterly, 15(4):533-552.

MAGADI, M.A. 2006. Poor pregnancy outcomes among adolescents in South Nyanza Region of Kenya. African Journal of Reproductive Health, 10(1):26-38.

MAHARAJ, P. 2006. Reasons for condom use among young people in KwaZulu-Natal: prevention of HIV, pregnancy or both? International Family Planning Perspectives, 32(1):28-34.

MALES, M. 1994. Poverty, rape, adult-teen sex: why prevention programmes don't work. Phi Delta Kappan, 75:407-410.

MANLOVE, J., TERRY-HUMEN, E. \& IKRAMULLAH, E. 2006. Young teenagers and older sexual partners: correlates and consequences for males and females. Perspectives on Sexual and Reproductive Health, 38(4):197-207. 
MANZINI, N. 2001. Sexual initiation and childbearing among adolescent girls in KwaZuluNatal, South Africa. Reproductive Health Matters, 9(17):44-52. [Online] Available: http://www.jstor.org/stable/3776397 [Accessed: 13/10/2009].

MARLOW, C. 1998. Research methods for generalist social work $\left(2^{\text {nd }}\right.$ ed). New York: Brookes/Cole Publishing Company.

MOLETSANE, R., MORELL, R., UNTERHALTER, E. \& EPSTEIN, D. 2002. Instituting gender equality in schools: working in an HIV/AIDS environment. Perspectives in Education, 20(2):37-53.

MORGAN, D.L. 1988. Focus groups as qualitative research. Newbury Park: Sage Publications.

MORRIS, T. 2006. Social work research methods: four alternative paradigms. Thousand Oaks, CA: Sage Publishers.

MPEDI, G. \& DARIMONT, A. 2007. The dualist approach to social security in developing countries: perspectives from China and South Africa. Journal of Social Development in Africa, 22(1):9-33.

ORME, J. 2002. Social work: gender, care and justice. British Journal of Social Work, 32:799-814.

PAYNE, M. 1991. Modern social work theory: a critical introduction. Chicago: Lyceum Books.

RANIGA, T. 2006. The implementation of the National Life-skills and HIV/AIDS School Policy and Programme in the eThekwini Region. Durban: University of KwaZulu-Natal. (Unpublished PhD Thesis)

RANIGA, T. \& SIMPSON, B. 2010. Poverty, HIV and the old age pension: a situational analysis of the elderly in Bhambayi. Development Southern Africa Journal. Forthcoming.

REPRODUCTIVE HEALTH RESEARCH UNIT. 2003. HIV and sexual behaviour among young South Africans: a National Survey of 15-24 year olds. University of Witwatersrand, South Africa.

RUTENBURG, N., KAUFMAN, C.E., MacINTYRE, K., BROWN, L. \& KARIM, A. 2003. Pregnant or positive: adolescent childbearing and HIV risk in KwaZulu-Natal, South Africa. Reproductive Health Matters, 11(22):122-133.

SATHIPARSAD, R. \& TAYLOR, M. 2006. Diseases come from girls: perspectives of male learners in rural KwaZulu-Natal on HIV infection and AIDS. Journal of Education, 38:117137.

SEWPAUL, V. 2005. Feminism and globalisation: the promise of Beijing and neoliberal capitalism in Africa. Agenda, 64:104-116.

SEWPAUL, V. 2006. The global-local dialectic: challenges for Africa scholarship and social work in a post-colonial world, British Journal of Social Work, 36:419-434.

SINGH, S. \& DARROCH, J. 1999. Adolescent pregnancy and childbearing: levels and trends in developed countries. Family Planning Perspectives, 32(1):14-23.

TERRE BLANCHE, M., DURRHEIM, K. \& PAINTER, D. 2006. Research in practice. Applied methods for social sciences. Cape Town: University of Cape Town Press. 
VAN DYK, A. 2005. HIVAIDS care and counselling: a multidisciplinary approach. Cape Town: Maskew Miller Longman (Pty) Ltd.

VAN RENSBURG, L.J. \& HORSTEN, D. 2004. The inadequacies of the Social Grant System available to children in South Africa. Journal for Juridical Sciences, 29(3):52-75.

WORLD HEALTH ORGANISATION (WHO). 2003. Integrating gender into HIV/AIDS programmes: a review paper. [Online] Available: http://www.who.int/gender [Accessed: 12/02/2009].

Dr Tanusha Raniga, Ms Sibonsile Mathe, School of Social Work and Community Development, University of KwaZulu-Natal, Howard College, Durban, South Africa. 